\title{
Analysis of Microbiological Test on Working Environment, Equipment and Personal Protective Equipment of Practical Students of Patient Infections
}

\author{
Hariyani, Indasah, Koesnadi \\ IIK Bhakti Wiyata Kediri, \\ Indonesia \\ Email: \\ hariyani_iik@yahoo.com
}

Received: March 12, 2019

Accepted: October 13, 2019

Published : November 26, 2019

\begin{abstract}
Prevention of infection in dentistry hospital by dentists, dental nurses, and clinical practice students plays an important role in controlling infection including maintaining hand hygiene, use of medical gloves, safe clothes, masks, protection of eyes and head and maintaining the sterility of equipment used for treatment patient. The purpose of this study was to analyze the effect of the use of work environments, equipment and personal protective equipment on practicing students on the incidence of infection of patients in dentistry hospital IIK Kediri. The research design used is quantitative research with observational analytic methods and uses a cross sectional approach. The sampling technique used was simple random sampling with a sample of 63 work environments, equipment and Personal Protective Equipment used by students practicing at dentistry hospital IIK Kediri. The results of the research data were analyzed by logistic regression test. The results of statistical analysis with logistic regression showed $p=0,000$ ( $p$ $<0,05)$, which means that there was influence of the work environment, equipment and personal protective equipment used by students to practice the incidence of infection in dentistry hospital IIK Kediri. Dental health professionals (dentists, dentistry students) who hold dental residencies and nurses and assistants must protect themselves and patients to avoid cross infection, cross contamination and work safety in dental practice.
\end{abstract}

Keywords : Dentisty Hospital, Equipment, Incidence of Patient Infection, Personal Protective Equipment, Working Environment 


\section{INTRODUCTION}

An environmental condition is said to be good or appropriate if humans can carry out their activities optimally, healthily, safely and comfortably. One of the benefits of creating a work environment is by minimizing the possibility of work accidents that can result in losses (Darmadi, 2008). The hospital as a work environment has potential dangers that can threaten the lives and lives of employees in hospitals, patients and visitors in the hospital. Hospitals in providing services aim to cure sick people, but hospitals can also be a source of infection.

Infection is basically an interaction between disease agents and susceptible hosts that occur through the transmission of certain germs. The way of transmitting disease agents, especially microorganisms that cause infection, can occur through blood, both droplet and airbone air, and direct contact. Dental health personnel is one of the health workers in the hospital who in the treatment of contact with saliva (saliva) and blood. Saliva and blood are intermediaries for transmission of infection so that the actions in the practice of dentists are at high risk. Dental health workers must increase awareness of transmission of infectious diseases both dentists, dental nurses, and clinical practice students (Ramadhani et al, 2015).Dentistry Hospital is a health service facility that carries individual dental and oral health services for treatment and recovery services without neglecting health improvement services and disease prevention carried out through outpatient, emergency and medical action services (Permenkes 1173, 2004).

In the initial survey conducted in March 2018, the average number of tooth extractions of patients in 2017 each month was 74 people. The incidence of infection in dentistry hospital IIK Bhakti Wiyata Kediri has never been conducted by Winarti Sih in January 2018 showing the incidence of infection in patients after tooth extraction was $17.8 \%$. Based on preliminary studies that have been carried out in the bacteriology laboratory of Institute of Health Sciences Bhakti Wiyata Kediri for five students practicing at Dentistry Hospital Bhakti Wiyata Kediri obtained the results of examination of the Personal Protective Equipment and the equipment used there are Staphylococus aureus and Escherecia Coli bacteria and the number of germs from the air in Dentistry Hospital Bhakti Wiyata Kediri treatment room is $320 \mathrm{CFU} / \mathrm{m} 3$.

Based on the background described, the researchers were interested in carrying out an Analysis of the Microbiological Test of the Working Environment, Personal Protective Equipment and equipment for practical students against the incidence of infection of patients in Dentistry Hospital Bhakti Wiyata Kediri.

\section{MATERIALS AND METHODS}

This research is a quantitative research with analytic observational research method and uses a cross sectional approach, where the data collection process is carried out simultaneously at the same time (Notoaatmodjo, 2012).Research conducted on April 25 - May 202018 at dentistry hospital IIK Bhakti Wiyata Kediri found that the patient population was removed as many as 74 people. Samples were taken randomly with an error rate of 5\%, with a total sample of 63 people. The instrument used for data collection was an observational sheet which included 10 signs of infection of tooth extracted patients in Dentistry Hospital Bhakti Wiyata Kediri which stated that there were infections if the infection marks were 1.3 and 7 were positive. The data obtained were tested by logistic regression to analyze the effect of independent variables on the dependent variable. Where the independent variables in this study are the work environment, equipment and personal protective equipment, while the dependent variable is the incidence of infection of patients in Dentistry Hospital Bhakti Wiyata Kediri.

\section{RESULT}

Based on the results of research conducted on April 25 - May 202018 in 63 patients, the following results were obtained: 


\section{CHARACTERISTIC OF RESPONDENTS}

1. Age of Characteristic of Respondents

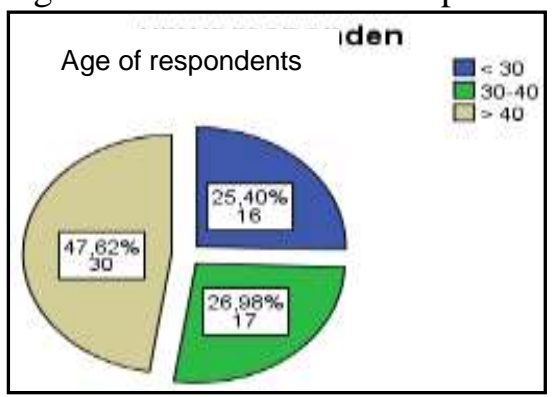

Figure 1. Distribution of Frequency of Age Characteristics of respondents in Dentistry Hospital Bhakti Wiyata on April 25 - May 202018

Based on Picture 1 shows that most respondents were> 40 years old as many as 30 respondents $(47.62 \%)$.

2. Characteristic of Gender Respondents

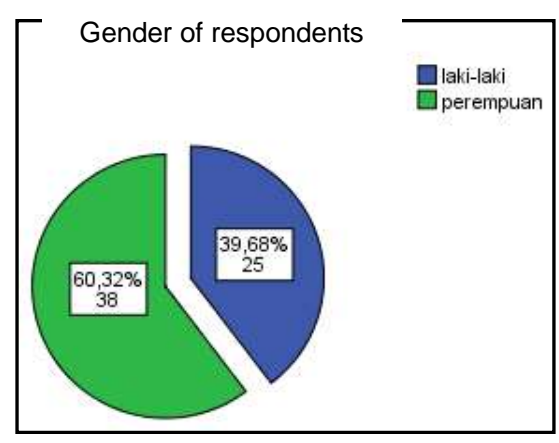

Figure 2. Distribution of the Frequency of Sex Characteristics of Respondents in Dentistry Hospital Bhakti Wiyata on April 25 - May 202018

Based on Figure 2 shows that most of the respondents were female, as many as 38 respondents (39.68\%).

3. Latest Educational Characteristics of Respondents

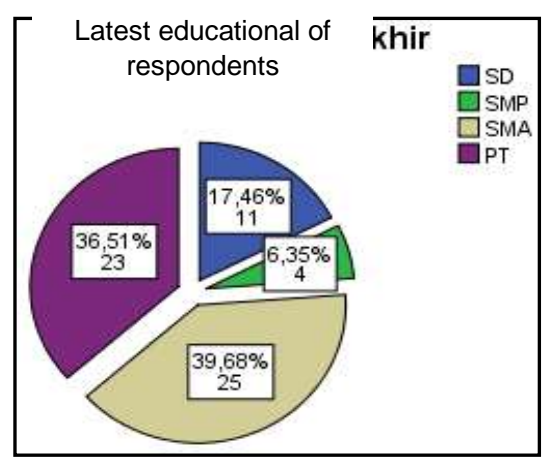

Figure 3. Frequency Distribution of the Latest Characteristics of Respondents in Dentistry Hospital IIK Bhakti Wiyata on April 25 - May 202018

Based on Figure 3 shows that most respondents with high school education were 25 respondents (25\%) 
4. Job Characteristics of Respondents

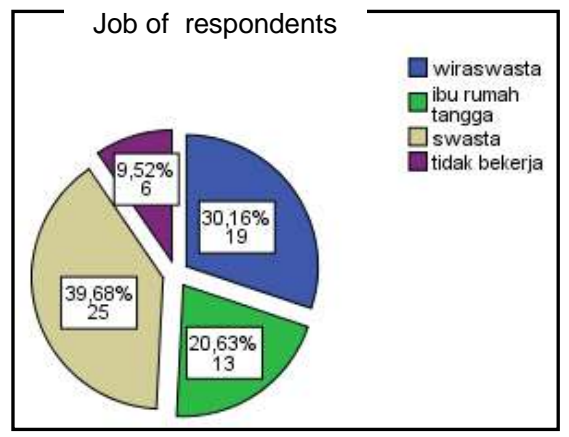

Figure 4. Frequency Distribution of Respondent's Job Characteristics at Dentistry Hospital IIK Bhakti Wiyata on April 25 - May 202018

Based on figure 4. shows that the majority of respondents who worked privately were 25 respondents $(39.68 \%)$.

5. Frequency distribution of the number of bacteria in the work environment (cubical) of students practice at Dentistry Hospital IIK Bhakti Wiyata Kediri on April 25 - May 202018

Table 1. The frequency distribution of the number of working environment (kubical) bacteria students practice at Dentistry Hospital IIK Bhakti Wiyata Kediri on April 25 - May 202018

\begin{tabular}{|c|c|c|}
\hline Characteristic & $\mathrm{N}$ & $\mathrm{f}(\%)$ \\
\hline Number of bacteria $(\mathrm{CFU} / \mathrm{m} 3)<200$ & 5 & 7.94 \\
\hline $200-500$ & 19 & 30.16 \\
\hline$>500$ & 39 & 61.90 \\
\hline Total & 63 & 100,0 \\
\hline
\end{tabular}

Based on the table 1 . shows the frequency of the number of working environment (cubical) bacteria practiced in Dentistry Hospital IIK Kediri, most of which contain cubic bacteria $>500 \mathrm{CFU} / \mathrm{m} 3$ as much as 39 cubic $(61.90 \%)$.

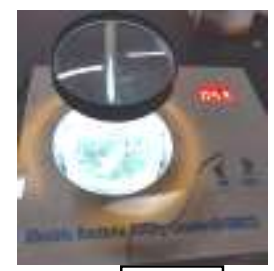

(a)

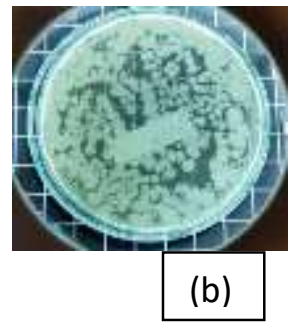

(b)

Figure 5 :

a. Colony counter to calculate the number of bacteria in the work environment

b. The results of identification of the number of working environment (cubical) bacteria in the students practicing at Dentistry Hospital IIK Kediri on May 20, 2018

6. Distribution of Frequency of Type of Equipment Bacteria (mouth glass) students practicing at dentistry hospital IIK Bhakti Wiyata Kediri

Table 2. Frequency distribution of types of equipment bacteria (mouth glass) of students practice at dentistry hospital IIK Kediri on April 25 - May 202018 


\begin{tabular}{cccc}
\hline Characteristic & $\mathrm{N}$ & $\mathrm{f}(\%)$ & gram \\
\hline Staphylococcus aureus & 26 & 41.27 & positif \\
\hline Escherecia coli & 9 & 14.27 & negatif \\
\hline Klebsiella pneumonia & 15 & 23.81 & negatif \\
\hline No bacteria & 13 & 20.63 & - \\
\hline Total & 63 & 100 & - \\
\hline
\end{tabular}

Based on table 2. shows the type of bacteria most of the equipment (mouth glass) of students practiced by students in tooth extraction patients in Dentistry Hospital IIK Kediri contained 26 Staphylococcus aureus bacteria (41.27\%).

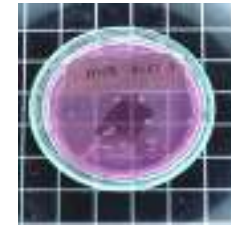

(a)

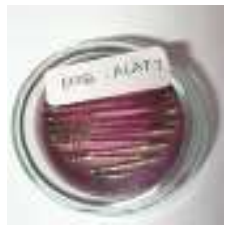

(b)

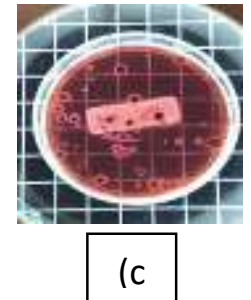

(c

Figure 6 :

The results of identification of types of bacteria in the equipment (mouth glass) of students practice at Dentistry Hospital IIK Bhakti Wiyata Kediri on April 25 - May 202018
a. Staphylococcus aureus bacteria
b. Escherecia coli bacteria
c. Klebsiella pneumonia bacteria

7. Frequency distribution of types of bacteria Personal Protective Equipment (gloves) students practice at Dentistry Hospital IIK Kediri on April 25-May 202018

Table 3. Frequency distribution of types of personal protective equipment (gloves) bacterial students practice at Dentistry Hospital IIK Kediri on April 25 - May 202018

\begin{tabular}{cccc}
\hline Characteristic & $\mathrm{N}$ & $\mathrm{f}(\%)$ & gram \\
\hline Staphylococcus aureus & 23 & 36.51 & positif \\
\hline Escherecia coli & 10 & 15.87 & negatif \\
\hline Klebsiella pneumonia & 12 & 19.05 & negatif \\
\hline No bacteria & 18 & 28.57 & - \\
\hline Total & 63 & 100 & - \\
\hline
\end{tabular}

Based on table 3. shows the type of bacteria most of the Personal Protective Equipment (gloves) used by students in tooth extraction patients in dentistry hospital IIK Kediri contained 23 Staphylococcus aureus bacteria $(36.51 \%)$. 


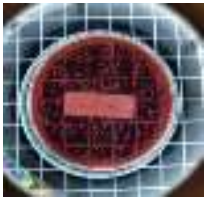

(a)
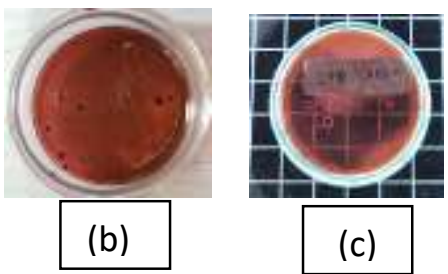

Figure 7:

Results of identification of types of bacteria in personal protective equipment (gloves) of students practice at Dentistry Hospital IIK Bhakti Wiyata Kediri on April 25 - May 202018

a. Staphylococcus aureus bacteria

b. Escherecia coli bacteria

c. Klebsiella pneumonia bacteria

Table 4. Morphological characteristics of bacterial equipment (mouth glass) and personal protective equipment (gloves) of students practice at Dentistry Hospital IIK Kediri

\begin{tabular}{lll}
\multicolumn{1}{c}{ Manitol Salt Agar } & \multicolumn{1}{c}{ Ehtylen Metilen Blue } \\
\hline \multicolumn{1}{c}{ Staphylococcus aureus } & \multicolumn{1}{c}{ Escherecia coli } & \multicolumn{1}{c}{ Klebsiella pneumonia } \\
\hline a. Round colony shape & a. Round colony shape & a. Big size \\
b. Round size & b. Small size & b. Round shape \\
c. White color & c. Sheen (shiny) metallic red & c. Red color of fish eyes \\
d. Flat bacterial edges & color & d. Convex surface \\
e. Convex surface & d. Flat edge & e. Mucoid consistency (slimy) \\
& e. Convex surface & \\
& f. Semi mucoid consistency & \\
& (slimy) & \\
\hline
\end{tabular}

8. Distribution of Frequency of Infection of Post-Displaced Patients based on the characteristics of respondents in dentistry hospital IIK Kediri on April 25 - May 202018

Table 5. Frequency distribution of infection of post-withdrawal patients at dentistry hospital IIK Kediri on April 25 - May 202018

\begin{tabular}{lcc}
\hline Characteristic & $\mathrm{N}$ & $\mathrm{f}(\%)$ \\
\hline $\begin{array}{l}\text { infection of post-withdrawal } \\
\text { patients }\end{array}$ & 45 & \\
No infection & 18 & 71.43 \\
\hline Infection & 63 & 28.57 \\
\hline Total & 63 & 100,0 \\
\hline
\end{tabular}

Based on Table 5 shows the majority of respondents post-withdrawal patients in dentistry hospital IIK Kediri did not occur after the pull out infection as many as 45 respondents $(71.43 \%)$. 


\section{ANALYSIS OF VARIABLES}

9. Cross Tabulation Identification of Number of Work Environment (Kubical) Bacteria with PostRevoke Patient Infection in dentistry hospital IIK Bhakti Wiyata Kediri

Table 6. Cross Tabulation Identification of the Amount of Working Environment (Cubical) Bacteria with Post-Revoke Patient Infection in dentistry hospital IIK Bhakti Wiyata on April 25 - May 202018

\begin{tabular}{|c|c|c|c|c|c|}
\hline & & & \multicolumn{2}{|c|}{ post-patient infection is removed } & \multirow{2}{*}{ Total } \\
\hline & & & No infection & Infection & \\
\hline \multirow{6}{*}{$\begin{array}{c}\text { Amount of working } \\
\text { environmentbacteria } \\
(\mathrm{CFU} / \mathrm{m} 3)\end{array}$} & \multirow{2}{*}{$<200$} & Total & 5 & 0 & 5 \\
\hline & & $\%$ & 7.9 & 0.0 & 7.9 \\
\hline & \multirow{2}{*}{$200-500$} & Total & 18 & 1 & 19 \\
\hline & & $\%$ & 28.6 & 1.6 & 30.2 \\
\hline & \multirow{2}{*}{$>500$} & Total & 22 & 17 & 39 \\
\hline & & $\%$ & 34.9 & 27.0 & 61.9 \\
\hline \multirow{3}{*}{ Total } & & Total & 45 & 18 & 63 \\
\hline & & $\%$ & 71.4 & 28.6 & 100,0 \\
\hline & Chi-square & & $\mathrm{p}=0.003(\mathrm{p}<0.05$ & & \\
\hline
\end{tabular}

Based on table 5. it is known that from most of the work environment (cubical) used for tooth extraction patients in dentistry hospital IIK the number of bacteria> $500 \mathrm{CFU} / \mathrm{m} 3$ was 39 cubic which did not cause infection as much as 22 cubic (34.9\%). The results of statistical tests with Chi-Square showed $p=0.003$, where $p<0.05$, which means that there was a significant effect of the identification of the number of bacteria in the place of withdrawal against the incidence of infection of post-patients in dentistry hospital IIK Bhakti Wiyata Kediri.

Cross Tabulation Identification of Type of Equipment Bacteria (Mouth Glass) of Students Practicing with Post-Revoked Patient Infection in dentistry hospital IIK Bhakti Wiyata Kediri.

Table 7. Cross Tabulation Identification of Student Equipment Type Bacteria Practicing with Post-Revoked Patient Infection in dentistry hospital IIK Bhakti Wiyata on April 25 - May 202018

\begin{tabular}{|c|c|c|c|c|c|}
\hline & & & \multicolumn{2}{|c|}{ Post-patient infection is removed } & \multirow{2}{*}{ Total } \\
\hline & & & No infection & Infection & \\
\hline \multirow{8}{*}{$\begin{array}{l}\text { Identification of } \\
\text { student equipment } \\
\text { type bacteria }\end{array}$} & \multirow{2}{*}{ Staphylococcus aureus } & Total & 14 & 12 & 26 \\
\hline & & $\%$ & 22.2 & 19.0 & 41.3 \\
\hline & \multirow{2}{*}{ Escherecia coli } & Total & 7 & 2 & 9 \\
\hline & & $\%$ & 11.1 & 3.2 & 14.3 \\
\hline & \multirow{2}{*}{ Klebsiella pneumonia } & Total & 11 & 4 & 15 \\
\hline & & $\%$ & 17.5 & 6.3 & 23,8 \\
\hline & \multirow{2}{*}{ No bacteria } & Total & 13 & 0 & 13 \\
\hline & & $\%$ & 20.6 & 0 & 20.6 \\
\hline \multirow{2}{*}{\multicolumn{2}{|c|}{ Total }} & Total & 45 & 18 & 63 \\
\hline & & $\%$ & 71.4 & 28.6 & 100,0 \\
\hline \multicolumn{3}{|c|}{ Chi-square } & $=0.025 \quad(\mathrm{p}<0,05$ & & \\
\hline
\end{tabular}


Based on table 6 it is known that most of the equipment (mouth glass) used by students practiced at dentistry hospital IIK which contained 26 Stapylococcus aureus bacteria (41.3\%) which did not cause 14 infections $(22.2 \%)$.

The results of statistical tests with Chi-Square showed $p=0.025$, where $p<0.05$, which means that there was a significant influence on the identification of bacterial types in the student practice equipment against the incidence of post-infection patients at dentistry hospital IIK Bhakti Wiyata Kediri.

10. Cross Tabulation Identification of Type of Personal Protective Equipment (gloves) Bacteria of students practicing with Post-Revoke Patient Infection in dentistry hospital IIK Bhakti Wiyata Kediri

Table 8. Cross Tabulation Identification of Type of Personal Protective Equipment (gloves) Bacteria of students practicing with Post-Revoke Patient Infection in the dentistry hospital IIK Bhakti Wiyata dated April 25 - May 202018

\begin{tabular}{|c|c|c|c|c|c|}
\hline & & & \multicolumn{2}{|c|}{ Post-patient infection is removed } & \multirow{2}{*}{ Total } \\
\hline & & & No infection & Infection & \\
\hline \multirow{8}{*}{$\begin{array}{l}\text { Identification of type } \\
\text { of Personal protective } \\
\text { equipment bacteria }\end{array}$} & \multirow{2}{*}{ Staphylococcus aureus } & Total & 11 & 12 & 23 \\
\hline & & $\%$ & 17.5 & 19.0 & 36.5 \\
\hline & \multirow{2}{*}{ Escherecia coli } & Total & 8 & 2 & 10 \\
\hline & & $\%$ & 12.7 & 3.2 & 15.9 \\
\hline & \multirow{2}{*}{ Klebsiella pneumonia } & Total & 8 & 4 & 12 \\
\hline & & $\%$ & 24,3 & 7,5 & 31,8 \\
\hline & \multirow{2}{*}{ No bakteria } & Total & 18 & 0 & 18 \\
\hline & & $\%$ & 28.6 & 0 & 28.6 \\
\hline \multirow{2}{*}{\multicolumn{2}{|c|}{ Total }} & Total & 45 & 18 & 63 \\
\hline & & $\%$ & 71.4 & 28.6 & 100,0 \\
\hline & Chi-square & $\mathrm{p}=0.00$ & $3(\mathrm{p}<0.05)$ & & \\
\hline
\end{tabular}

Based on table 7. it is known that most of the Personal Protective Equipment (gloves) used by students practice in dentistry hospital IIK Bhakti Wiyata which contains 23 Staphylococcus aureus bacteria (36.5\%) which causes 12 infections (19.0\%). The results of statistical tests with Chi-Square showed a value of $p=0.003$, where $p<0.05$, which means that there was a significant influence on the identification of types of bacteria in the Personal Protective Equipment (gloves) on the incidence of infection of post-withdrawal patients at dentistry hospital IIK Bhakti Wiyata Kediri .

\section{DATA ANALYSIS}

To determine the effect of microbiological tests on the work environment, equipment and personal protective equipment for students on the incidence of post-infection, remove it in the dentistry hospital IIK Bhakti Wiyata Kediri using statistical analysis, namely logistic regression. The results of the SPSS analysis using logistic regression are as follows: 
Table 9. Table Omnibus Test of Model Coefficients logistic regression Microbiological test of working environment, equipment and Personal Protective Equipment for practicing students on the incidence of infection of patients in the dentistry hospital IIK Bhakti Wiyata

\begin{tabular}{|c|c|c|c|c|}
\hline & & Chi-square & $\mathrm{df}$ & Sig. \\
\hline \multirow{3}{*}{ Step 1} & Step & 23,892 & 3 & , 000 \\
\hline & Block & 23,892 & 3 &, 000 \\
\hline & Model & 23,892 & 3 &, 000 \\
\hline \multirow{3}{*}{ Step $2^{\mathrm{a}}$} & Step & $-1,523$ & 1 & ,217 \\
\hline & Block & 22,369 & 2 &, 000 \\
\hline & Model & 22,369 & 2 & ,000 \\
\hline
\end{tabular}

Based on Table 9. shows the results of the analysis using logistic regression seen simultaneously $\mathrm{p}$ value $=0.000(\mathrm{p}<0.05)$ that the number of bacteria working environment (cubical), equipment and Personal Protective Equipment students practice together have an effect on the incidence of infection of the tooth extracted at dentistry hospital IIK Bhakti Wiyata Kediri.

Table 10. Table Model Summary logistic regression Microbiological test of working environment, equipment and Personal Protective Equipment for practicing students on the incidence of infection of patients in dentistry hospital IIK Bhakti Wiyata Kediri

\begin{tabular}{cccc}
\hline Step & -2 Log likelihood & Cox \& Snell R Square & Nagelkerke R Square \\
\hline 1 & $51,490^{\mathrm{a}}$ &, 316 &, 452 \\
\hline 2 & $53,013^{\mathrm{b}}$ &, 299 &, 428 \\
\hline
\end{tabular}

Table 10. shows that the results of the analysis with logistic regression are seen simultaneously, the value of Cox and Snell $=0.299$ and Nagelkerke $=0.428$, which means that the diversity of data that can be explained by the logistic regression model is $29.9 \%$ of all available data, and variable capabilities free in explaining the dependent variable is $42.8 \%$ and there are $57.3 \%$ other factors outside the model that explain the dependent variable.

Tabel 11. Tabel Variables in the Equation logistic regression Microbiological test of working environment, equipment and Personal Protective Equipment for practicing students on the incidence of infection of patients in dentistry hospital IIK Bhakti Wiyata Kediri

\begin{tabular}{|c|c|c|c|c|c|c|c|}
\hline & & $\mathrm{B}$ & S.E. & Wald & df & Sig. & $\operatorname{Exp}(B)$ \\
\hline \multirow{4}{*}{ Step $1^{\mathrm{a}}$} & Bacteria_equipment & ,461 & ,382 & 1,460 & 1 & ,227 & 1,586 \\
\hline & $\begin{array}{l}\text { bacteria_ } \\
\text { APD }\end{array}$ &, 538 & ,388 & 1,918 & 1 & ,166 & 1,713 \\
\hline & $\begin{array}{l}\text { bacteria_ } \\
\text { working environment }\end{array}$ & $-2,362$ & 1,097 & 4,636 & 1 & ,031 & ,094 \\
\hline & Constant & 5,328 & 3,295 & 2,616 & 1 &, 106 & 206,092 \\
\hline Step $2^{\mathrm{a}}$ & $\begin{array}{l}\text { bacteria_ } \\
\text { APD }\end{array}$ &, 837 & ,323 & 6,724 & 1 &, 010 & 2,310 \\
\hline
\end{tabular}




\begin{tabular}{lcccccc}
$\begin{array}{l}\text { bacteria_ } \\
\text { working environment }\end{array}$ & $-2,409$ & 1,076 & 5,010 & 1 &, 025 &, 090 \\
\hline Constant & 5,813 & 3,184 & 3,334 & 1 &, 068 & 334,611 \\
\hline
\end{tabular}

Based on table 10 shows that the results of the analysis with logistic regression when viewed in partial (individual) variables that influence the incidence of infection of patients are Personal Protective Equipment (gloves) with a value of $p=0.01(p<0.05)$ and the number of environmental bacteria work (cubical) with a value of $\mathrm{p}=0.025$ ( $\mathrm{p}<0.05$ ). Whereas equipment (mouth glass) with a value of $p=0.227(p>0.05)$ did not affect the incidence of infection of the patient.

From the data from the analysis above, it is known that the most dominant variable influential is the student's self-protective equipment against the incidence of infection of post-withdrawal patients in the dentistry hospital IIK Bhakti Wiyata with a value of $p=0.01$.

\section{DISCUSSION}

\section{Identification of the number of bacteria in the student's work environment in dentistry hospital IIK Bhakti Wiyata Kediri}

Identification of the number of bacteria in the work environment of students practicing at the dentistry hospital IIK Bhakti Wiyata conducted on April 25 - May 202018 showed that of the 63 cubic counts, the number of bacteria <200 CFU / $\mathrm{m} 3$ was 5 cubic (7.94\%), bacterial number 200- $500 \mathrm{CFU} /$ $\mathrm{m} 3$ as much as 19 cubic feet (30.16\%), total bacteria> 500 CFU / m3 as much as 39 cubic $(61.90 \%)$. The work environment retrieval process is carried out for 30 minutes by placing bacterial media on the dental practice unit of the student which means that for 1 minute it can suck up as much as 40 liters of air so that the number of germ colonies formed using a coloni counter is calculated. Sampling was carried out at one point of work environment in the Dentistry treatment room with a germicidal index in the recovery / treatment room with a maximum concentration of microorganisms per $\mathrm{m} 3$ of air is 200-500 CFU / m3 (Kepmenkes, 2004).

The environment of the Dentistry hospital IIK Bhakti Wiyata for air circulation treatment rooms uses artificial / mechanical ventilation which is using exhausfan only treatment rooms using air conditioning. Lack of treatment space is not available space between the outside air and there is no inter cubical distance (where the dental unit is located). The disinfectant used for environmental cleaning at the Dentistry hospital IIK Kediri is a solution of clorhexsidin. Supposedly for the treatment room sterilization in the dentistry hospital IIK Kediri using Ultraviolet rays where after all the action is done sterilization of the room so that the next day is sterile and can be used for treatment actions. Besides that, the floor in the dentistry hospital IIK Kediri has an angle on each corner so this causes bacterial contamination from saliva or the blood of the affected patient is left on the floor which is difficult to clean. The condition of the treatment room for patients pulling teeth in the dentistry hospital IIK kediri should have a separate room to minimize bacterial contamination during the tooth extraction process.

\section{Identification of bacterial types Student equipment practices in dentistry hospital IIK Bhakti Wiyata Kediri}

Identification of the type of bacterial equipment (mouth glass) used by students in the practice of tooth extraction patients in the dentistry hospital IIK Bhakti Wiyata contained 26 Staphylococcus aureus bacteria (41.27\%), 9 Escherecia coli bacteria (14.27)\% and as many as Klebsiella pneumonia bacteria 15 tools $(23.81 \%)$. Where as student equipment with no bacteria was $13(20.63 \%)$. The gram-positive bacteria found in student equipment practice is that Staphylococcus aureus becomes a parasite in the skin and nose causing lung, bone, heart and vascular infections. Whereas gram negative bacteria are Escherichia coli and Klebsiella cause gastrointestinal infections (Jawetz, 2008).

Some students clean the equipment contaminated with running water and soap then take it to the sterilization room, but do not pay attention to self-protection when cleaning the appliance. Students should clean the appliance by using $0.5 \%$ chlorine solution and sterilize the appliance before using it again. The unavailability of personal protective equipment when cleaning equipment and lack of student awareness resulted in the prevention of infection when handling instruments were ignored by most clinical clerical students of the Dentistry Hospital IIK Bhakti Wiyata Kediri. 


\section{Identification of the number of bacteria in the student's personal protective equipment in dentistry hospital IIK Bhakti Wiyata}

Identification of microbiological tests of Personal Protective Equipment (gloves) used by students in tooth extract patients in the dentistry hospital IIK Bhakti Wiyata showed that there were 23 Staphylococcus aureus bacteria (36.51\%), 10 (15.87\%) Escherecia coli and 12 (19.05\%) Klebsiella pneumonia ) While the Personal Protective Equipment with no bacteria was 18 (28.57\%).

In this case the contaminated cause of personal protective equipment for students practices by bacteria is caused by factors that come from medical personnel, paramedics and the environment. Normally these bacteria live in their respective habitats, for example Staphylococcus aureus. This bacterium is a normal flora in the oral cavity. Although as a normal flora in certain circumstances these bacteria can turn into pathogens due to predisposing factors, namely oral hygiene. The bacteria Staphylococcus aureus is also a normal flora in the head hair, students do not use a head covering when acting on patients so that this causes a source of wound contamination in tooth marks. At the time of handwashing students before doing treatments that do not use antiseptics so that they cannot remove the bacteria completely which still have bacteria on their hands. Then bacteria also come from contaminated cloth when students use a cloth after washing their hands.

\section{Identification the incidence of infection in post-withdrawal patients dentistry hospital IIK Bhakti Wiyata}

The identification of the incidence of infection of post-withdrawal patients in the dentistry hospital IIK Bhakti Wiyata Kediri was carried out using an observation sheet on the tooth extractor patient where previously the patient filled out the research approval sheet and the characteristics of the respondent. After that the researchers examined the signs of infection when the control patients on the third day after tooth extraction included observation of heat, rubor, tumors, examination of sockets, lymph nodes, dolor, pus, trismus and fungiolaesia. The results showed that of the 63 respondents who did not have post-pull infection, there were 45 respondents $(71.43 \%)$ and there were 18 respondents (28.57\%). Most of the tooth extract patients in dentistry hospital IIK Bhakti Wiyata Kediri did not experience post tooth extraction, while the incidence of infection in patients with tooth extraction was due to the presence of remaining roots in the patches that still felt pain and there was an oral surgery process that required sutures causing the surgery to last long this causes bacterial contamination.

At the time of control, 3-7 days after removal of the patient / respondent was examined with 10 signs of infection. If at least there are signs number 3, 7 and 10, then there is an infection. Patients who have post-pulling infection have at least signs of swelling in the gingiva, there is a complaint of pain in the scars, and the side of the mouth where there are chipped wounds can not be done to chew. Students who do tooth extraction with long roots are rather difficult, and usually require a long extraction time, and the wound is rather large. This is what increases the risk of infection. Staphylococcus aureus is a normal human flora microstructure found in the airways and skin. Serious infection will occur when the patient's resistance is decreased if there is a wound. Most of the diseases caused by Staphylococcus aureus produce pus therefore Staphylococcus aureus bacteria are called pyogenic.

Analyze the number of bacteria the student's work environment practices against the incidence of infection of post-withdrawal patients in dentistry hospital IIK Bhakti Wiyata Kediri

The results of the analysis of the number of bacteria in the work environment is known that from 63 cavities used by the students the practice is for tooth extraction patients in dentistry hospital IIK Bhakti Wiyata with the number of bacteria $<200 \mathrm{CFU} / \mathrm{m} 3$ as much as 5 cubic which does not cause infection. The number of bacteria is $200-500 \mathrm{CFU} / \mathrm{m} 3$ as much as 19 cubic which causes 1 (1.6\%) infection. Whereas 39 cubic bacteria> $500 \mathrm{CFU} / \mathrm{m} 3$ caused 17 (27.0\%) infections. Statistical test results with logistic regression showed the value of $p=0.025$, where $p<0.05$, which means there is a significant influence on the identification of the number of bacteria in the work environment (where to pull) to the incidence of infection of post-patients in the dentistry hospital IIK Bhakti Wiyata Kediri.

The interval between sessions that are too short (10 minutes) causes the janitor to rush into cleaning the cubicles. Sometimes it is also only swept without disinfecting the dental unit. Likewise, students sometimes also did not have the chance to change the fabric of the dental unit cover and tablecloth in the table. The trash that students provided for the next session work was sometimes not 
replaced. The facts found in the field need to get serious attention by increasing the time lag, also the garbage control in cubical, so that the trash is replaced every time the session changes.

\section{Analysis of bacterial types Practical student equipment for the incidence of post-infection patients withdraw in dentistry hospital IIK Bhakti Wiyata IIK Kediri}

The results of bacterial type analysis (mouth glass) equipment used by students to practice the incidence of tooth extraction in the dentistry hospital IIK Bhakti Wiyata revealed that out of 63 equipment used by students the practice of 26 Stapylococcus aureus bacteria (41.3\%) caused as many infections. 12 (19.0\%). While those containing Escherecia coli bacteria were $9(14.3 \%)$ which caused 7 infections (11.1\%). Containing $15(23.8 \%)$ Klebsiella pneumonia bacteria which caused 4 infections $(6.3 \%)$. Whereas those that do not contain bacteria are $13(20.6 \%)$. Which is classified as gram positive bacteria is Stapylococcus aureus while those classified as gram negative bacteria are Escherecia coli and Klebsiella pneumonia.

The results of statistical tests with logistic regression showed $p=0.227$, where $p<0.05$, which means that there was no significant effect on the identification of bacterial types on the student practice equipment on the incidence of post-infection patients at the dentistry hospital IIK Bhakti Wiyata Bhakti Wiyata Kediri. This is due to the limited sterilization equipment owned by dentistry hospital IIK Bhakti Wiyata which uses dry sterilizers while for hospital sterilizers the standard must use autoclaves with high temperature heating and wet sterilization processes to ensure the sterility of the equipment to be used.

\section{Analysis of the type of bacteria the student's self-protective equipment practices against the incidence of post-infection patients withdraw in dentistry hospital IIK Bhakti Wiyata Kediri}

The results of bacterial type analysis of Personal Protective Equipment used by students in the practice of the occurrence of post-infection infection in the dentistry hospital IIK Bhakti Wiyata Kediri is known that of the 63 Personal Protective Equipment (gloves) containing 23 Staphylococcus aureus bacteria (36.5\%) which caused infection $12(19.0 \%)$. Contains 10 Escherecia coli bacteria (15.9\%) which causes 2 infections (3.2\%). Contains 12 bacteria (Klebsiella pneumonia) (31.8\%) and causes 4 (7.5\%) infections. While the Personal Protective Equipment with no bacteria was 18 (28.6\%). Statistical test results with logistic regression showed the value of $p=0.01$ where $p<0.05$, which means that there is a significant effect of the identification of bacteria on the Personal Protective Equipment (gloves) on the incidence of infection of post-patients in the dentistry hospital IIK Bhakti Wiyata Kediri. This is because the gloves that are used do not go through the sterilization process when they are to be used, but the direct retrieval process is by the warehouse officer of dentistry hospital IIK Bhakti Wiyata Kediri from the packaging of gloves in the box so that in this case the gloves used are not sterile.

\section{The influence of the most dominant variables on the incidence of post-patient infection is} withdrawal in dentistry hospital IIK Bhakti Wiyata Kediri

To determine the effect of microbiological tests on the work environment, equipment and personal protective equipment for students on the incidence of post-infection, remove it in the dentistry hospital IIK Bhakti Wiyata Kediri using statistical analysis, namely logistic regression.

From the results of the data analysis with logistic regression partially or individually known the most dominant variable influencing is the type of bacterial self-protective student practice against the incidence of infection of post-withdrawal patients in the dentistry hospital IIK Bhakti Wiyata with a value of $\mathrm{p}=0.01(\mathrm{p}<0.05)$ Type of bacteria Student's personal protective equipment is the most dominant variable influencing the incidence of post-infection withdrawal in the dentistry hospital IIK Bhakti Wiyata because bacterial contamination can occur through the action of washing hands with water or antiseptic, using personal protective equipment (gloves, masks, face shields), glasses), equipment handling and environmental hygiene, the use of disinfectants (dental units) moves through the hands of paramedics and medical personnel direct contact with saliva (blood saliva) and the patient's blood. 


\section{CONCLUSION}

The number of bacteria in the work environment affects the incidence of infection in the dentistry hospital IIK Bhakti Wiyata $(\mathrm{p}=0.025)$. The type of bacteria in the student's (glass mouth) equipment does not affect the incidence of infection in the dentistry hospital IIK Bhakti Wiyata $(p=0.227)$. Types of bacteria in the Personal Protective Equipment (gloves) of practical students affect the incidence of infections in dentistry hospital IIK Bhakti Wiyata kediri $(p=0.01)$. The most dominant influence on the incidence of infection of post-withdrawal patients in the dentistry hospital IIK Bhakti Wiyata is the type of self-protective bacteria with a value of $p=0.01(\mathrm{p}<0.05)$.

\section{REFERENCES}

Darmadi. (2008). Infeksi Nosokomial, Problematika dan pengendaliannya, Jakarta: Salemba Medika.

Ernawati, et al. (2011). Penerapan Hand Hygiene perawat di ruang rawat inap Rumah sakit. Jurnal Kedokteran Brawijaya.

Jawetz, Melnick, \& Adelberg's. (2008). Mikrobiologi Kedokteran. Salemba Medika. Jakarta.

Keputusan Menteri Kesehatan Republik Indonesia Nomor 1069/MENKES/SK/XI/2008 tentang Pedoman klasifikasi dan Standar Rumah Sakit Pendidikan.

Keputusan Menteri Kesehatan Republik Indonesia Nomor 1204/Menkes/SK/X/2004 tentang Persyaratan Kesehatan Lingkungan Rumah Sakit.

Keputusan Menteri Kesehatan Republik Indonesia Nomor 1335/MENKES/SK/X/2002 tentang standar Operasional Pengambilan dan Pengukuran Sampel Kualitas Udara Ruangan Rumah Sakit.

Notoatmodjo, S. (2012). Metodologi Penelitian Kesehatan. Jakarta: Rineka Cipta.

Peraturan Menteri Kesehatan Republik Indonesia Nomor 1173/MENKES/PER/X/2004 tentang Rumah Sakit Gigi dan Mulut.

Eka, P., Arfina. (2013). Prevalensi komplikasi pencabutan gigi di RSGM Drg. Halimah Dgr Sikati FKG UNHAS periode April-Mei 2013.

Ramadhani W., R., Billy, J., Kepel, Wulan, G., \& Parengkuan. (2015). Tindakan Pencegahan dan Pengendalian Infeksi pada Perawatan Periodonsia di Rumah Sakit Gigi dan Mulut PSPG FK UNSRAT. Universitas Sam Ratulangi Manado. Jurnal e-GiGi (eG). Volume 3. Nomor 2. JuliDesember 2015 diakses pada 31 Januari 2018. 